Article

\title{
Extraction Optimization of Flavonoids from Hypericum formosanum and Matrix Metalloproteinase-1 Inhibitory Activity
}

\author{
Ho-Shin Huang ${ }^{1,2}$ and Ean-Tun Liaw ${ }^{1, *}$ \\ 1 Department of Food Science, National Pingtung University of Science \& Technology, Pingtung 91201, \\ Taiwan; adinol.huang@gmail.com \\ 2 Testing Center of Cosmetic, Tridl Inc., Tainan 70955, Taiwan \\ * Correspondence: alexliaw@mail.npust.edu.tw; Tel.: +886-8-774-0368
}

Received: 17 October 2017; Accepted: 2 December 2017; Published: 11 December 2017

\begin{abstract}
Hypericum formosanum is a valuable herb in Taiwan. In this study, response surface methodology was employed to optimize the ultrasound-assisted extraction of flavonoids from Hypericum formosanum. A central composite design with three variables (ethanol concentration, extraction time, and extraction temperature) was applied. Experimental results were fitted to the second order polynomial model and one-way analysis of variance was used to determine the goodness of fit of the model and the optimal conditions for responses. The optimal conditions for the maximum extraction yield of total flavonoid content $(101.1 \mathrm{mg} / \mathrm{g})$ using ultrasound-assisted extraction were ethanol concentration, 73.5\%; extraction time, $38.3 \mathrm{~min}$; and extraction temperature, $62.5^{\circ} \mathrm{C}$. The predicted result was consistent with the experimental result obtained under optimal extraction conditions. Hyperoside, astilbin, quercitrin, and quercetin from Hypericum formosanum extract (HFE) were identified by Ultra performance liquid chromatography-diode array detector-mass (UPLC-DAD-MS). HFE significantly reduced matrix metalloproteinase-1 protein expression in human skin keratinocyte cells, induced by advanced glycation end products.
\end{abstract}

Keywords: response surface methodology; Hypericum formosanum; matrix metalloproteinase-1; flavonoids

\section{Introduction}

In various parts of the world, plants of genus Hypericum have been used in traditional medicines, as an antiseptic, and as an antispasmodic, as well as in the treatment of external wounds and gastric ulcers [1]. Plants of the genus Hypericum spp. are a rich source of flavonoids and exhibit a broad spectrum of activities. The flavonoids and their derivatives, isolated from different species of Hypericum, exhibit potent anti-tumor, anti-fungal, anti-microbial [2-4], anti-ulcer, anti-depressant, antioxidant, and anti-inflammatory activities [5-7]. Hypericum formosanum is native to Taiwan and is a valuable folk herb in Taiwan. However, to the best of our knowledge, there are no reports in literature on the extraction of flavonoids from Hypericum formosanum.

In recent years, many studies have focused on extraction optimization of flavonoids and their health and medicinal applications [8-10]. Ultrasound assisted extraction (UAE) is established as a useful technique for the extraction of polyphenol and flavonoid compounds from plant sources, and has been found to be more effective than other extraction methods [11-13]. Moreover, recent studies have demonstrated the effects of several parameters on the extraction of flavonoid compounds from some herbs, using response surface methodology (RSM) [14-16]. RSM is widely employed as an effective modeling tool to construct functional relationships between a response variable and design variables. Several studies on conditions optimized for the extraction of phenolic compounds from different sources using RSM have been published [17-20]. Central composite design (CCD) is the 
most popular form of RSM and has been widely used for analysis to optimize various parameters in extraction conditions [21]. The efficiency of extraction depends on several parameters, such as temperature, time, and solvent polarity, and their effects can be either independent or interactive [22,23]. In this study, UAE was used to extract flavonoids from the whole plant Hypericum formosanum, and the effects of ethanol percentage, extraction time, and extraction temperature on the total flavonoid content (TFC) were studied. Extraction conditions were then optimized using response surface methodology.

The process of skin aging can be divided into intrinsic and extrinsic categories. Intrinsic aging is caused by the aging process and is highly correlated with genetic factors. However, extrinsic aging is mainly due to exposure to ultraviolet (UV) light and is characterized by severe wrinkling and collagen degradation [24,25]. Glycation resulting from UV light exposure, genetic factors, and environmental pollution promotes skin aging [26,27]. Glycation causes advanced glycation end products (AGEs) to accumulate in the skin during skin aging, especially in long-lived proteins such as dermal elastin and collagen [28,29]. Matrix metalloproteinases (MMPs) are zinc-dependent endopeptidases that are important in the remodeling of extracellular matrix (ECM) structure in skin. MMP-1 is a collagenase, and plays an essential role in the physiological mechanism of skin aging [30]. AGEs could increase the expression of MMP-1 in human keratinocyte cells. It has been reported that flavonoids have inhibitory effects on glycation processes and cause decreased MMP-1 expression [31]. Flavonoids are efficient antioxidants that possess anti-cancer and anti-aging activities [32]. In our study, we found quercitrin was the major compound in the extract from Hypericum formosanum. Quercitrin is a bioflavonoid with antioxidant properties and is better absorbed than other forms of quercetin [33]. Additionally, quercitrin showed excellent inhibitory effects on AGE formation and good anti-glycation activity [34,35]. In this study, the inhibitory activities of the Hypericum formosanum extract and quercitrin on MMP-1 were also evaluated.

\section{Results and Discussion}

\subsection{Effects of Time, Ethanol Concentration, and Temperature on the Extraction of Flavonoids}

To examine the effects of ethanol concentration on the extraction of flavonoids, a range of 30-75\% solvent concentration was tested in this study. Our results revealed that ethanol concentrations of about $70 \%$ resulted in the highest flavonoid value (Figure $1 \mathrm{a}$ ) and that flavonoid extraction yield was greatly influenced by the concentration of ethanol. The reasons for this might be related to the polarity of ethanol and the solubility of flavonoids in Hypericum formosanum. Figure $1 \mathrm{~b}$ shows that flavonoid values increased as extraction time increased from 40 to $50 \mathrm{~min}$. After extraction time exceeded $50 \mathrm{~min}$, the extraction rate dropped. Longer extraction times may enhance extraction efficiency, but may also increase the oxidation of phenolic compounds [21].

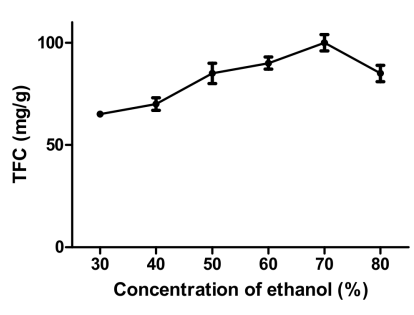

(a)

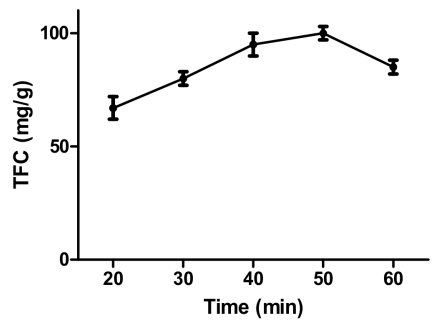

(b)

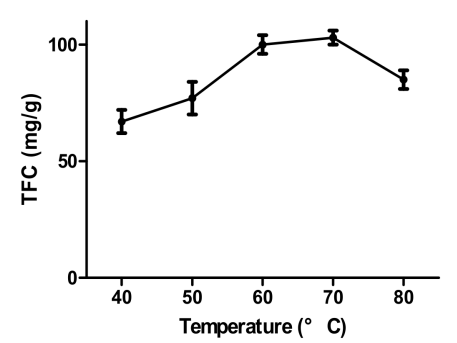

(c)

Figure 1. The effects of (a) concentration of ethanol; (b) extraction time; and (c) extraction temperature on the total flavonoid content (TFC) of the extract $(N=3)$.

Extraction temperature was another important factor for the extraction of flavonoids from herbs. This study showed, as shown in Figure 1c, the TFC of the Hypericum formosanum extract (HFE) increased with an increase in temperature up to $70{ }^{\circ} \mathrm{C}$, with a maximum TFC at $60-70{ }^{\circ} \mathrm{C}$. These results are 
explained by the fact that the release of bioactive compounds from plant cells can be increased by an increase in extraction temperature, but temperatures higher than the optimized level may cause the decomposition of several thermo-sensitive compounds within the extract [36].

\subsection{Fitting the Model and Response Surface Analysis}

Based on the procedures for central composite design experiments, the values of the independent variables were chosen based on the values obtained from the single-factor experiments. Ethanol concentration $(A, \%, v / v)$, extraction time $(B, \min )$, and extraction temperature $\left(C,{ }^{\circ} \mathrm{C}\right)$, which have a significant effect on the extraction rate of total flavonoids, were selected as design variables for the RSM test. The RSM test was designed using the extraction rate of TFC ( $\mathrm{mg} / \mathrm{g}$ ) as the response variable (Table 1). Results showed that the TFC values ranged from 65.5 to $101.5 \mathrm{mg} / \mathrm{g}$ dry weight (DW). A quadratic polynomial model using multiple regression analysis could describe the results of the CCD. One-way analysis of variance (ANOVA) for the fitted equation is illustrated in Table 2. The F-test was conducted to check whether the regression equation was statistically significant. The $F$-value was high (28.33) and the $p$-value was low (<0.0001), which implied the model obtained was statistically significant. In addition, the determination coefficient value $\left(R^{2}\right)$ was 0.9587 , which implies strong correlation between the predicted results and the actual results. In addition, the lack of fit was not significant $(F=2.89 ; p=0.1342>0.05)$, indicating that variation is predicted by the model [23]. These data revealed that the model was appropriate for forecasting TFC values of HFE within the tested ranges. In this model, the linear parameter $\mathrm{X}_{1}$ was significant at the level of $p<0.0001$, and the interaction parameter $X_{1} X_{2}$ and quadratic terms $X_{2}{ }^{2}$ and $X_{3}{ }^{2}$ were significant $(p<0.05)$ for the extraction yield of flavonoids. The linear parameters $X_{2}$ and $X_{3}$, the interaction parameters $X_{1} X_{3}$ and $X_{2} X_{3}$, and the quadratic term $X_{1}{ }^{2}$, were not significant $(p>0.05)$. After discarding the insignificant parameters, the regression model was modified as below:

$$
Y=93.28+10.17 A+1.78 B+3.25 C+0.98 A B+0.33 A C-1.02 B C-1.26 A^{2}-4.41 B-9.36 C^{2}
$$

The graph of RSM was a 3D response surface plot consisting of response values of the experimental variables (Figure 2), which reflects the interactions between the variables (ethanol concentration, extraction time, and extraction temperature). The combined effect of ethanol concentration and extraction time was not significant; as can be seen in Figure 2a the effect of extraction time on the extraction rate of flavonoids was not very obvious at a given ethanol concentration as the surface is relatively flat. Figure $2 \mathrm{~b}$ shows the $3 \mathrm{D}$ response surfaces for the combined effect of ethanol concentration and extraction temperature on TFC, and it reveals that at low ethanol concentration and high extraction temperature values, the TFC was minimal. When extraction temperature was at a certain value, the TFC increased with an increase in ethanol concentration. However, it was not significant that the increase in the extraction temperature affected the TFC at a certain ethanol concentration. As shown in Figure 3c, extraction time and extraction temperature demonstrated a quadratic effect on the response. Based on the results of the response surface plots and ANOVA, it is obvious that ethanol concentration was the main parameter influencing the TFC value.

Table 1. Factors and levels in the response surface central composite design arrangement and experimental results.

\begin{tabular}{ccccc}
\hline \multirow{2}{*}{ Run } & $\mathbf{X}_{\mathbf{1}}$ & $\mathbf{X}_{\mathbf{2}}$ & $\mathbf{X}_{\mathbf{3}}$ & Response Value \\
\cline { 2 - 5 } & $\begin{array}{c}\text { Concentration } \\
\text { of Ethanol (\%) }\end{array}$ & $\begin{array}{c}\text { Extraction } \\
\text { Time (min) }\end{array}$ & $\begin{array}{c}\text { Extraction } \\
\text { Temperature }\left({ }^{\circ} \mathbf{C}\right)\end{array}$ & TFC (mg/g) \\
\hline 1 & 75 & 20 & 80 & 90.1 \\
2 & 52.5 & 40 & 60 & 89.9 \\
3 & 30 & 20 & 40 & 65.5 \\
4 & 30 & 40 & 60 & 80.2 \\
5 & 30 & 60 & 80 & 70.5 \\
\hline
\end{tabular}


Table 1. Cont

\begin{tabular}{ccccc}
\hline \multirow{2}{*}{ Run } & $\mathbf{X}_{\mathbf{1}}$ & $\mathbf{X}_{\mathbf{2}}$ & $\mathbf{X}_{\mathbf{3}}$ & Response Value \\
\cline { 2 - 5 } & $\begin{array}{c}\text { Concentration } \\
\text { of Ethanol (\%) }\end{array}$ & $\begin{array}{c}\text { Extraction } \\
\text { Time (min) }\end{array}$ & $\begin{array}{c}\text { Extraction } \\
\text { Temperature }\left({ }^{\circ} \mathbf{C}\right)\end{array}$ & TFC (mg/g) \\
\hline 6 & 75 & 20 & 40 & 81.9 \\
7 & 52.5 & 40 & 60 & 94.7 \\
8 & 75 & 40 & 60 & 101.5 \\
9 & 52.5 & 40 & 60 & 94.5 \\
10 & 52.5 & 40 & 80 & 90.2 \\
11 & 52.5 & 40 & 40 & 75.3 \\
12 & 30 & 20 & 80 & 70.2 \\
13 & 52.5 & 60 & 60 & 90.2 \\
14 & 30 & 60 & 40 & 67.7 \\
15 & 75 & 60 & 80 & 92.1 \\
16 & 52.5 & 20 & 60 & 85.2 \\
17 & 52.5 & 40 & 60 & 95.2 \\
18 & 75 & 60 & 40 & 90.2 \\
19 & 52.5 & 40 & 60 & 94.9 \\
20 & 52.5 & 40 & 60 & 95.1 \\
\hline
\end{tabular}

Table 2. Analysis of variance for the quadratic polynomial model.

\begin{tabular}{ccccccc}
\hline Source & Sum of Squares & $\mathbf{d f}$ & Mean Square & $\boldsymbol{F}$-Value & $\boldsymbol{p}$-Value & Significant \\
\hline Model & 2084.65 & 9 & 231.63 & 28.33 & $<0.0001$ & Significant \\
$\mathrm{X}_{1}$ & 1034.29 & 1 & 1034.29 & 126.5 & $<0.0001$ & \\
$\mathrm{X}_{2}$ & 31.68 & 1 & 31.68 & 3.88 & 0.1234 & \\
$\mathrm{X}_{3}$ & 105.62 & 1 & 105.62 & 12.92 & 0.0773 & \\
$\mathrm{X}_{1} \mathrm{X}_{2}$ & 7.61 & 1 & 7.61 & 0.93 & 0.0049 & \\
$\mathrm{X}_{1} \mathrm{X}_{3}$ & 0.84 & 1 & 0.84 & 0.1 & 0.3576 & \\
$\mathrm{X}_{2} \mathrm{X}_{3}$ & 8.4 & 1 & 8.4 & 1.03 & 0.7545 & \\
$\mathrm{X}_{1}^{2}$ & 4.39 & 1 & 4.39 & 0.54 & 0.3345 & \\
$\mathrm{X}_{2}^{2}$ & 53.57 & 1 & 53.57 & 6.55 & 0.0284 & \\
$\mathrm{X}_{3}^{2}$ & 241.11 & 1 & 241.11 & 29.49 & 0.0003 & \\
Residual & 81.76 & 10 & 8.18 & & & \\
Lack of Fit & 60.77 & 5 & 12.15 & 2.89 & 0.1342 & Not significant \\
Pure Error & 20.99 & 5 & 4.20 & & & \\
Core total & 2166.41 & 19 & & & & \\
$R^{2}$ & 0.9587 & & & & & \\
\hline
\end{tabular}

\subsection{Optimization and Verification}

By using Design Expert 8.0 software (Stat-Ease, Minneapolis, MN, USA), the optimum conditions were obtained. The optimal conditions for the maximum extraction yield of total flavonoid content $(101.1 \mathrm{mg} / \mathrm{g})$ using ultrasound-assisted extraction were ethanol concentration, $73.5 \%$; extraction time, $38.3 \mathrm{~min}$; and extraction temperature time, $62.5^{\circ} \mathrm{C}$. The results showed that the experimental values $(101.7 \mathrm{mg} / \mathrm{g}$ ) were not only consistent with the predictive values (Table 3), but were also better than any single factor experiments. Therefore, the extraction conditions obtained by RSM were not only accurate and reliable, but also of practical value reflecting the expected optimization. This study shows that the extraction of flavonoids from Hypericum formosanum can be improved by optimizing extraction parameters.

Table 3. The results of experimental verification.

\begin{tabular}{ccccc}
\hline \multicolumn{2}{c}{ Optimal Conditions } & \multicolumn{2}{c}{ Total Flavonoid Content (mg/g) } \\
\hline $\begin{array}{c}\text { Concentration of } \\
\text { Ethanol (\%) }\end{array}$ & Time (min) & Temperature $\left({ }^{\circ} \mathrm{C}\right)$ & Experimental Result & Predicted Value \\
\hline 73.5 & 38.3 & 62.5 & $101.7 \pm 1.7$ & 101.1 \\
\hline
\end{tabular}


(a)

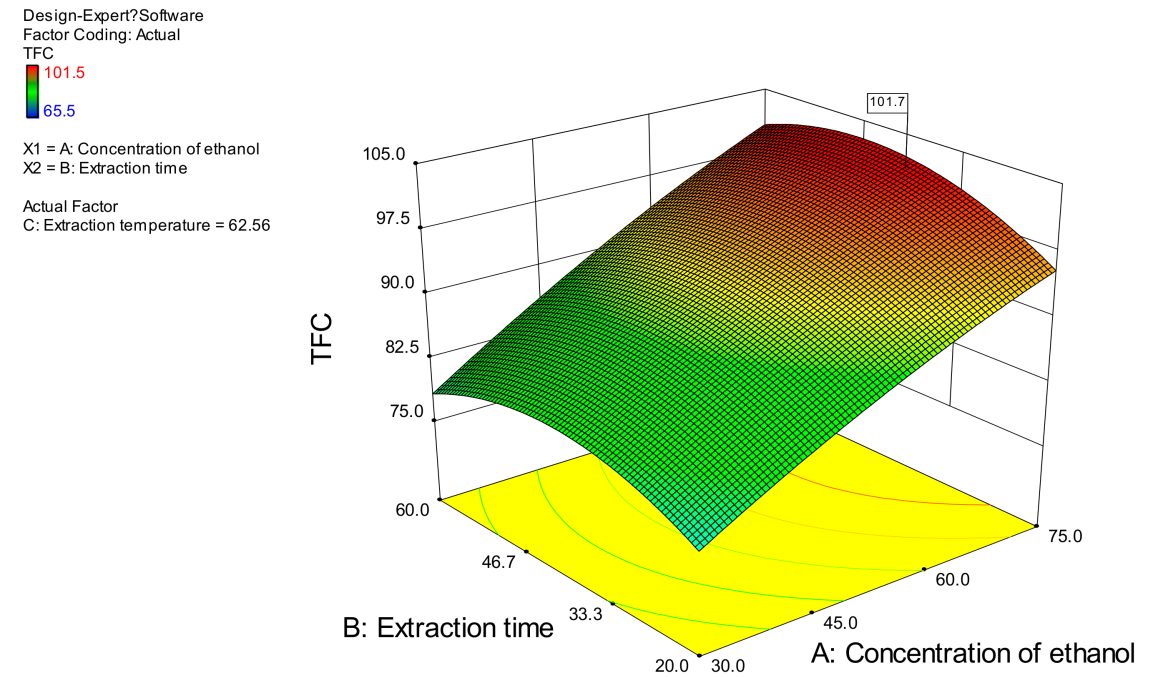

(b)

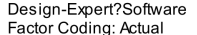

Factor Coding: Actual

$\prod_{65.5}^{101.5}$

$\mathrm{X} 1=\mathrm{A} \cdot$ Concentration of ethanol

Actual Factor

B: Exraction time $=40.63$

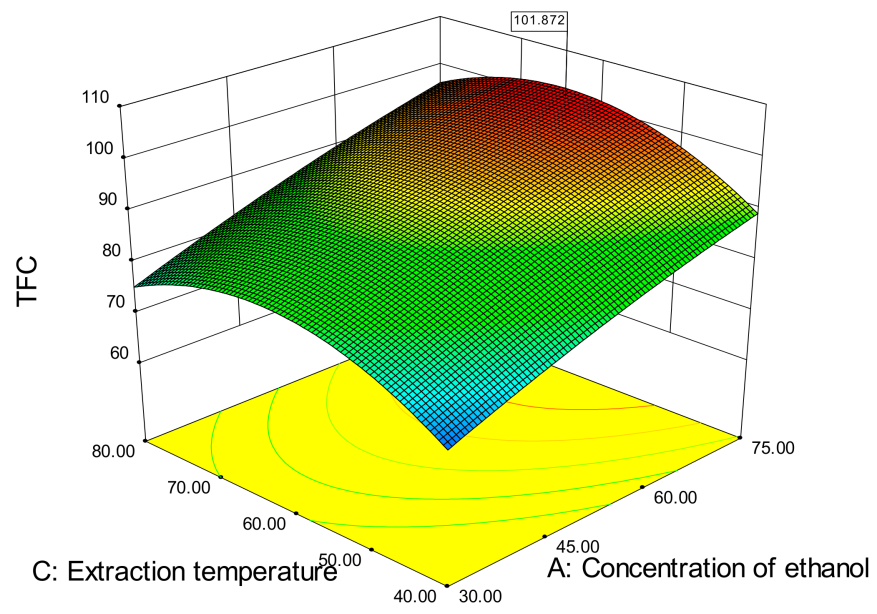

Design-Expert? Softwar

Factor Coding: Actual

TFC 101.5

$\mathrm{X} 1=\mathrm{B}:$ Extraction time X $=\mathrm{C}:$ Extraction temperature Actual Factor

Ac.

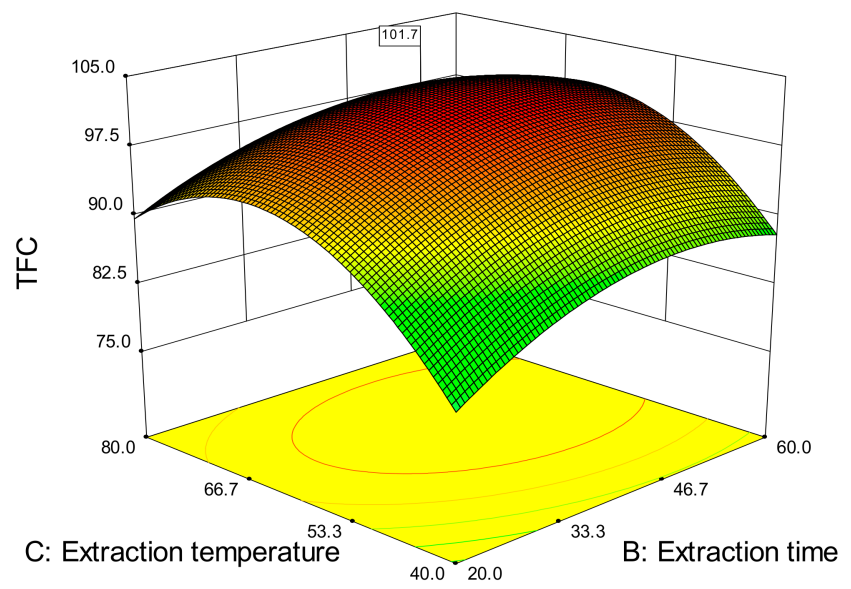

Figure 2. Response surface plots (3D) showing the effects of different extraction parameters including (a) concentration of ethanol; (b) extraction time and (c) extraction temperature on the response. 


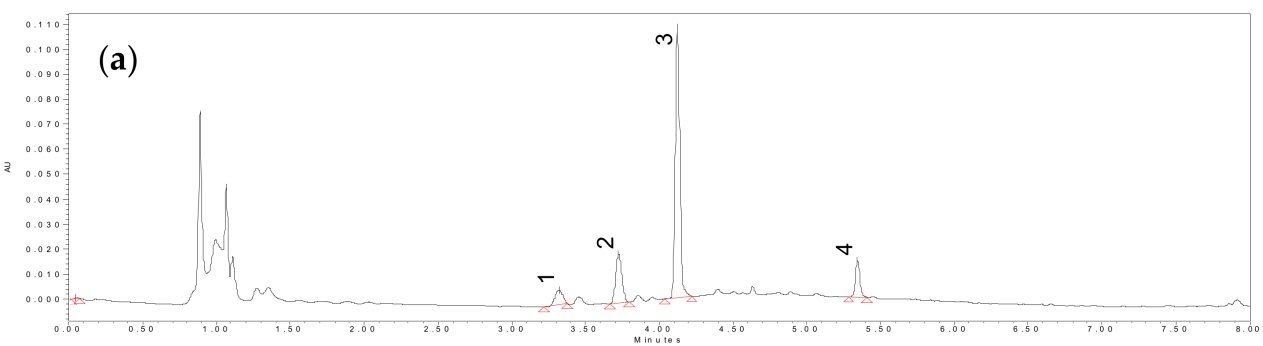

(b)

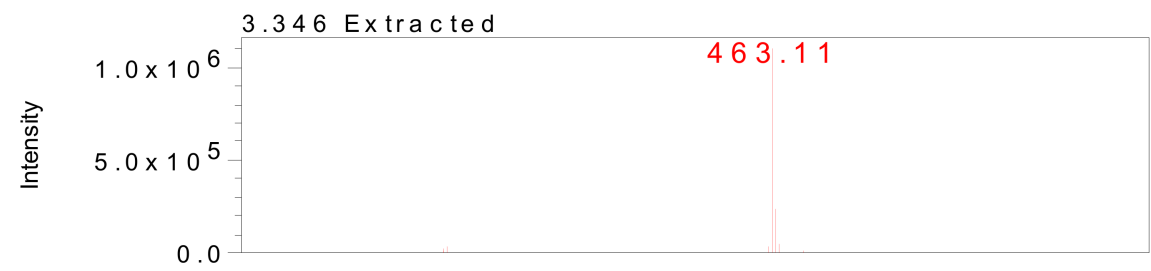

(c)

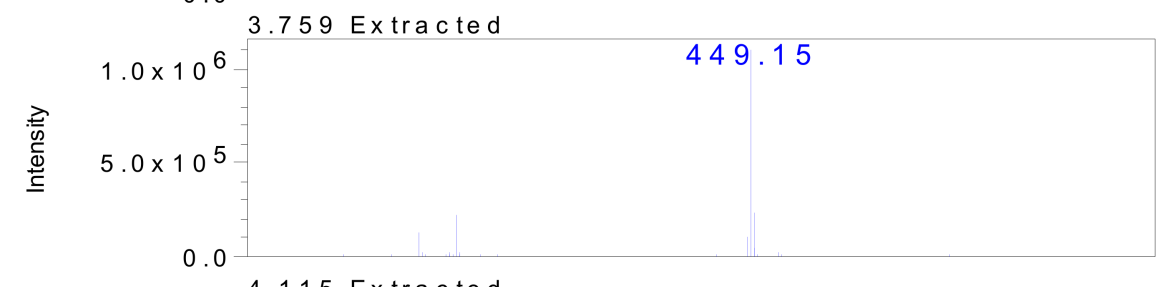

(d)

(e)

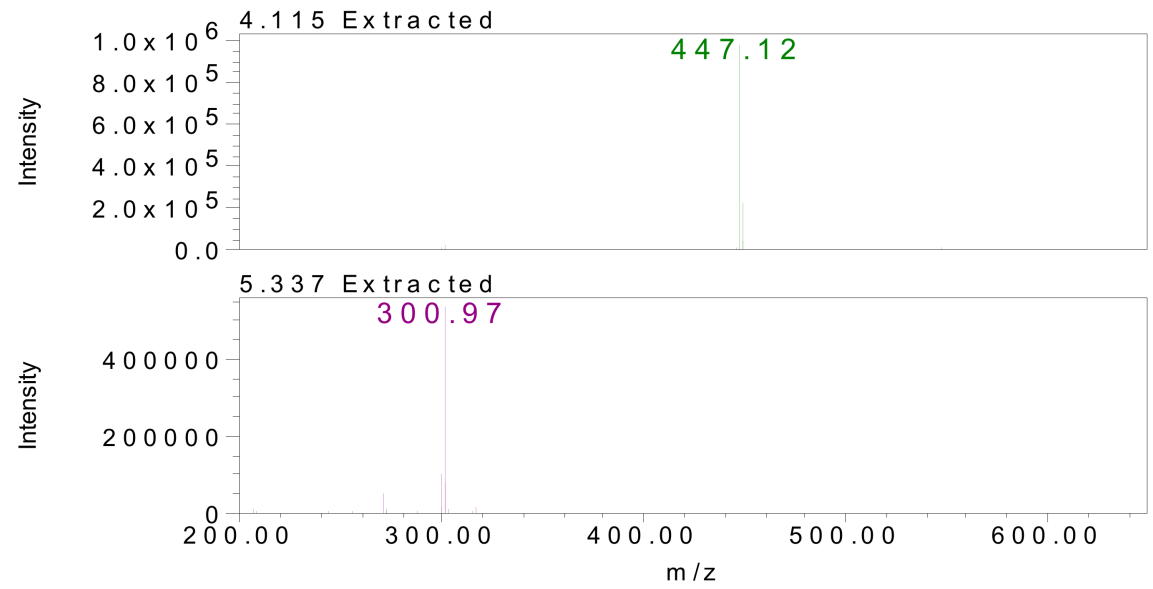

Figure 3. UPLC-DAD chromatograms obtained at $270 \mathrm{~nm}$ from Hypericum formosanum extract (HFE);

(a) 1 = Hyperoside, 2 = Astilbin, 3 = Quercitrin, 4 = Quercetin; (b) MS of Hyperoside; (c) MS of Astilbin;

(d) MS of Quercitrin; (e) MS of Quercetin.

\subsection{Identification of Bioactive Compounds by HPLC-MS Analysis}

Medicinal plant extracts and isolated secondary metabolites have traditionally been used to treat a wide variety of diseases with acute and chronic inflammation. Fruits and vegetables are important anti-inflammatory compounds due to their potent anti-oxidative activity and this is especially true for flavonoids in herbs [37]. In addition, flavonoids are often involved in the pharmacological activity of important medicinal plants. In previous studies, plants of the Hypericum genus have been shown to contain many bioactive compounds, including phloroglucinols, naphthodianthrones, flavonoids (hyperoside, rutin, quercetin, quercitrin, isoquercitrin, miquelianin, astilbin), and phenolic acids (chlorogenic acid) [5,6]. In this study, the high performance liquid chromatography (HPLC) chromatographic profile of Hypericum formosanum extract was shown in Figure 3a-c. The major compounds of Hypericum formosanum, including hyperoside (1), astilbin (2), quercitrin (3), and quercetin (4), were identified by Ultra performance liquid chromatography-diode array detector-mass (UPLC-DAD-MS) analysis and comparing their mass data with standards. 


\subsection{Matrix Metalloproteinase-1 Inhibitory Activity}

Cell viabilities were measured by 3-(4,5-dimethylthiazol-2-yl)-2,5-diphenyltetrazolium bromide (MTT) assay. Treatment of Human skin keratinocyte cells (HaCaT cells) with HFE and quercitrin at various concentrations from 250 to $500 \mu \mathrm{g} / \mathrm{mL}$ for $24 \mathrm{~h}$ exhibited that cell viability was more than $90 \%$. MMP-1, also called collagenase-1, is chiefly responsible for the degradation of type I collagen, a primary component in and structural support for the skin dermis [29]. It is believed that the flavonoids in herb extracts play an important role in MMP inhibition and other anti-proliferative effects [38]. Our study found AGEs raised MMP-1 expression in HaCaT cells (Figure 4). Data revealed that HFE and quercitrin treatment at 250-500 $\mu \mathrm{g} / \mathrm{mL}$ markedly down-regulated MMP- 1 in this cell line $(p<0.05)$. The level of MMP-1 protein decreased significantly by $58 \pm 1.2 \%$ and $66 \pm 2.3 \%$ compared to the control level at concentrations of $250 \mu \mathrm{g} / \mathrm{mL}$ and $500 \mu \mathrm{g} / \mathrm{mL}$ of HFE, respectively. As shown in Figure 4, quercitrin suppressed AGE-induced MMP-1 expression by $30 \pm 1.7 \%$ and $67 \pm 2.0 \%$ compared to the control level at the concentrations of $250 \mu \mathrm{g} / \mathrm{mL}$ and $500 \mu \mathrm{g} / \mathrm{mL}$, respectively. Some studies have found that flavonoid compounds from herbs provided significant inhibitory effects on UVB-induced matrix MMP-1 expression in HaCaT cells [39]. Similarly, we found quercitrin shows significant activity, indicating that quercitrin plays an important role in MMP-1 inhibitory activity. In addition, the inhibitory activity of HFE, which contains multiple compounds, was better than quercitrin at $250 \mu \mathrm{g} / \mathrm{mL}$. Some studies have suggested herbal extracts show stronger and more effective bioactivity effects than any of the single compounds due to the coordination of numerous natural compounds [40,41]. Results from our study also showed similar results; that the multiple compounds within herb extracts might increase MMP-1 inhibitory activity by a synergistic effect. However, further in vivo studies are necessary to elucidate its MMP inhibitory activity and synergistic effect mechanisms.

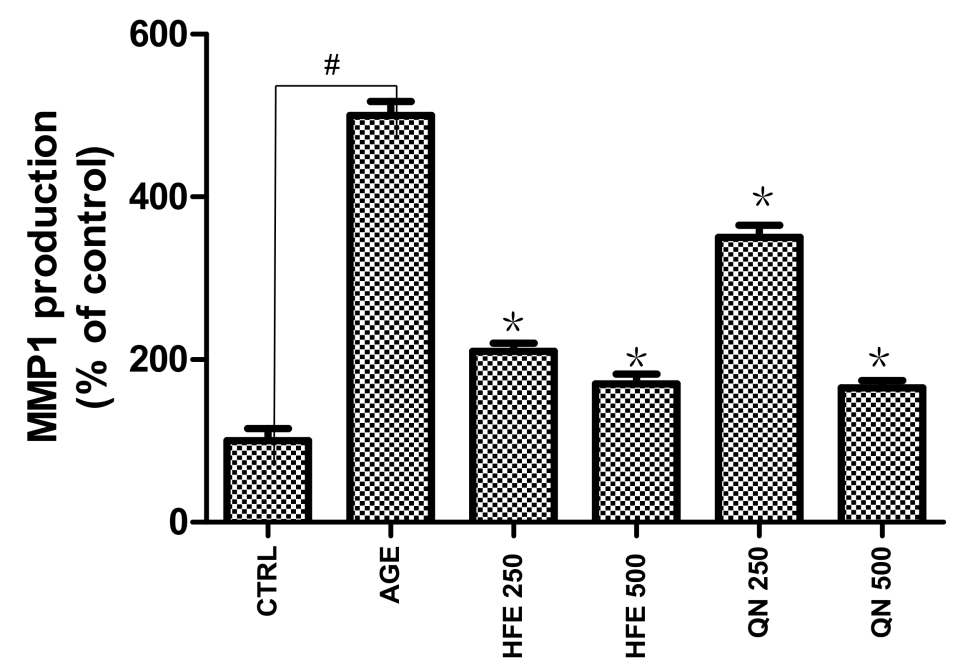

Figure 4. Effects of HFE and QN (quercitrin) on Matrix metalloproteinase 1 (MMP-1) expression in human skin keratinocyte (HaCaT) treated by advanced glycation end products (AGEs) for $24 \mathrm{~h}$. Data are shown as the mean \pm standard deviation (SD) of three independent experiments (Positive control: 24 h AGE-induced \#: $p<0.05$ compared to negative control; *: $p<0.05$ compared to positive control by Student's $t$-test).

\section{Materials and Methods}

\subsection{Plant Materials}

The tissues of Hypericum formosanum, including the leaves, stem, and roots, were harvested. The plant material was identified by Dr. Chang, San-Xian, botanist of the Hualien District Agricultural Research and Extension Station Council of Agriculture. The plant materials were washed with water 
and air-dried at room temperature for 5 days. The sample was then oven-dried at $55^{\circ} \mathrm{C}$ for 2 days and ground to a fine powder by an electronic blender.

\subsection{Chemicals}

Methanol, ethanol, acetonitrile, formic acid, aluminium chloride $\left(\mathrm{AlCl}_{3}\right)$, sodium nitrite $\left(\mathrm{NaNO}_{2}\right)$, sodium hydroxide $(\mathrm{NaOH})$, and Advanced glycation end products (AGEs) were purchased from Merck Co. (Darmstadt, Germany). Dimethyl sulfoxide (DMSO), streptomycin, phosphate buffer saline, 3-(4,5-Dimethylthiazol-2-yl)-2,5-diphenyltetrazolium bromide (MTT), catechin, hyperoside, quercitrin, quercetin, and astilbin and were purchased from Sigma Co. (St. Louis, MO, USA). Fetal bovine serum (FBS) and Dulbecco's Modified Eagle's Medium (DMEM) were purchased from Gibco (Invitrogen, Carlsbad, CA, USA).

\subsection{Plant Materials and Preparation of the Extracts}

The powder of Hypericum formosanum tissue was extracted with ethanol using an ultra-sonicator. For ultrasound-assisted extraction, a sonication water bath (Delta, DC-400H, Taipei, Taiwan with a frequency fixed at $40 \mathrm{kHz}$ was used. In experimental runs, $0.5 \mathrm{~g}$ of Hypericum formosanum powder was mixed with $50 \mathrm{~mL}$ of ethanol at various concentrations (according to the study design) in $100 \mathrm{~mL}$ flasks. After extraction, the extracts were instantly filtered through the filter paper under reduced pressure. Extracts were collected into glass flasks and stored at $4{ }^{\circ} \mathrm{C}$ until further analysis.

\subsection{Total Flavonoid Content}

Total flavonoid content (TFC) was determined based on Kim's method [42] with some modifications. One $\mathrm{mL}$ of diluted extract solution $(1 \mathrm{mg} / \mathrm{mL})$ was mixed with $0.3 \mathrm{~mL}$ of $5 \% \mathrm{NaNO}_{2}$ and $4 \mathrm{~mL}$ of distilled water. $0.3 \mathrm{~mL}$ of $10 \% \mathrm{AlCl}_{3}$ was added to the mixture followed by adding $2 \mathrm{~mL}$ of $1 \mathrm{M} \mathrm{NaOH}$. The solution was immediately diluted to $10 \mathrm{~mL}$ using distilled water. The absorbance of the solution was measured at $510 \mathrm{~nm}$. Results of total flavonoid content were expressed as $\mathrm{g}$ of catechin equivalents (CE) on dry weight of dry extract (mg CE/g DW). All experiments were performed in triplicate.

\subsection{Single-Factor Experiments}

In order to investigate the influence of every factor on the TFC of the Hypericum formosanum extract, single-factor experiments were conducted as to determine the effects of the five different factors. Concentration of ethanol (30-75\%), extraction time (20-60 $\mathrm{min})$, and temperature $\left(30-60{ }^{\circ} \mathrm{C}\right)$ were determined on the basis of the TFC yield.

\subsection{Experimental Design}

To evaluate the effect of each factor on the total flavonoid content of the Hypericum formosanum extract, a single-factor experimental design was first adopted for analyzing the influence of the three different variables. The effects of the concentration of ethanol, extraction temperature, and extraction time were investigated. Optimization of the UAE of TFC from the Hypericum formosanum was further carried out using RSM [22]. A three-factor and three-level CCD consisting of twenty experimental runs was employed at the center point (Table 4). The experimental data were fitted to the second-order polynomial equation given below:

$$
Y=\beta_{0}+\Sigma \beta \mathrm{i} X \mathrm{i}+\Sigma \beta \mathrm{ii} \mathrm{Xi}^{2}+\Sigma \beta \mathrm{ij} \mathrm{XiXj}
$$

where $Y$ is the predicted response (TFC), and $\beta_{0}, \beta \mathrm{i}, \beta \mathrm{ii}$, and $\beta \mathrm{ij}$ are the regression coefficients for the intercept, linear, quadratic, and interaction terms, respectively. $X_{i}$ and $X_{j}$ are independent variables. 
Table 4. Independent variables and their coded and actual values used for optimization.

\begin{tabular}{lcccc}
\hline \multirow{2}{*}{ Independent Variable } & \multirow{2}{*}{ Symbol } & \multicolumn{4}{c}{ Coded Levels } \\
\cline { 3 - 5 } & & $\mathbf{- 1}$ & $\mathbf{0}$ & $\mathbf{1}$ \\
\hline Concentration of ethanol (\%) & $\mathrm{X}_{1}$ & 30 & 60 & 75 \\
Time (min) & $\mathrm{X}_{2}$ & 20 & 40 & 60 \\
Temperature $\left({ }^{\circ} \mathrm{C}\right)$ & $\mathrm{X}_{3}$ & 40 & 60 & 80 \\
\hline
\end{tabular}

The design of experiments, analysis of the results, and prediction of the responses were performed using Design-Expert software 8.0 (Stat-Ease, Minneapolis, MN, USA). Comparisons of the means were performed using one-way analysis of variance. The extraction conditions were optimized for the maximum yield of TFC based on the regression analysis and the 3D surface plots of the independent variables. Finally, the predicted values were compared with the experimental values to determine the validity of the model.

\subsection{UPLC-DAD-MS Analysis of the Extract}

The HFE samples, dissolved in methanol, were separated on an RP-C18 column (XBridge $2.5 \mu \mathrm{m}$, $\mathrm{C} 18,100 \times 2.1 \mathrm{~mm}$ ) by UPLC equipped with a Waters Acquity system consisting of a column oven, sample manager, solvent manager, and DAD detector (Waters Corp., Milford, MA, USA). The flow rate was $0.4 \mathrm{~mL} / \mathrm{min}$. The solvent gradient for UPLC was a mixture of $0.1 \%$ formic acid $/ \mathrm{H}_{2} \mathrm{O}$ (solvent A) and $0.1 \%$ formic acid/acetonitrile (solvent B): $85 \%$ A from 0 to $3 \mathrm{~min}, 45-65 \%$ A from 3 to $5 \mathrm{~min}$, and $45-0 \%$ A from 5 to $8 \mathrm{~min}$. The column temperature was fixed at $40{ }^{\circ} \mathrm{C}$. A $270 \mathrm{~nm}$ wavelength was employed to quantify the flavonoids. Identification of the constituents was carried out with a Waters Acquity QDa Mass Detector with an Electro Spray Ionization (ESI) source, and Empower software (Waters, Milford, MA, USA) was used for data analysis. Negative ion mass spectra were recorded in the range $m / z 200-650$. Probe temperature was kept at $600{ }^{\circ} \mathrm{C}$ and Cone Voltage at $30 \mathrm{~V}$.

\subsection{Cell Culture}

A human skin keratinocyte (HaCaT) cell line from American Type Culture Collection (ATCC, Rockville, MD, USA) was cultured in Dulbecco's Modified Eagle's medium (DMEM) supplemented with $10 \%$ fetal bovine serum and $100 \mathrm{U} / \mathrm{mL}$ streptomycin under $95 \%$ air $/ 5 \% \mathrm{CO}_{2}$ at $37^{\circ} \mathrm{C}$. Culture medium was changed every three days, cells were sub-cultured once a week, medium was changed to serum-deprived medium, and cells were washed with serum-free DMEM $24 \mathrm{~h}$ before experiments and replanted in 96-well plates. Phosphate buffered saline (PBS, pH 7.2) was used to adjust cell number to $10^{5} / \mathrm{mL}$ for various experiments and analyses.

\subsection{Cell viability Assay}

Cell viability was analyzed using a 3-(4,5-dimethylthiazol-2-yl)-2,5-diphenyltetrazolium bromide (MTT) assay. HaCaT cells were seeded in the wells of 96-well plates and incubated with HFE $(250,500,1000 \mu \mathrm{g} / \mathrm{mL})$ and quercitrin for $24 \mathrm{~h}$. After incubation, MTT solution was treated for $4 \mathrm{~h}$. The culture medium was removed and the formazan crystals that had formed were dissolved in DMSO and quantified at $570 \mathrm{~nm}$ using a microplate reader (MultiskanGO, Thermo Fisher Scientific Inc., Waltham, MA, USA).

\subsection{AGEsTreatment and Real-Time PCR Analysis}

HaCaT cells $\left(10^{5}\right.$ cells $\left./ \mathrm{mL}\right)$ were treated with AGEs at $100 \mu \mathrm{g} / \mathrm{mL}$ for $24 \mathrm{~h}$ at $37^{\circ} \mathrm{C}$. After washing with serum-free DMEM, cells were exposed to Hypericum formosanum extract and quercitrin at $250 \mu \mathrm{g} / \mathrm{mL}$ and $500 \mu \mathrm{g} / \mathrm{mL}$ for $24 \mathrm{~h}$. Control groups were HaCaT cells containing neither AGEs nor Hypericum formosanum extract. After $24 \mathrm{~h}$ mRNA was extracted from cells using Trizol Reagent (Invitrogen-Thermo Fisher Scientific, Waltham, MA, USA) according to the manufacturer. cDNA was obtained from $0.5-1 \mathrm{mg}$ of total mRNA 
using Moloney Murine Leukemia Virus Reverse Transcriptase, MMLV-RT (Promega, Madison, WI, USA) according to the manufacturer. The mRNA relative expression was determined by real-time PCR using Fast Start Universal SYBR Green Master Mix (Roche, Basel, Switzerland) in a real-time PCR-System machine (Sure Tect, Thermo Fisher Scientific Inc., Waltham, MA, USA). The primer was MMP-1 (Forward: 5'-ATGCTGAAACCCTGAAGGTG-3', Reverse: 5'-GAGCATCCCCTCCAATACCT-3') and the internal control, GAPDH (Forward: 5'-CTCATGACCACAGTCCATGC-3', Reverse: 5'-CACATTGG GGGTAGGAACAC-3').

\subsection{Statistical Analysis}

Design Expert 8.0 was applied in the statistical analysis of the results in the RSM experiment. SPSS19.0 (IBM, Armonk, NY, USA) and Excel 2016 (Microsoft, Redmond, Washington, USA) were used for statistical analysis during the entire study.

\section{Conclusions}

In this study, a method by RSM optimization has been developed to extract flavonoids from Hypericum formosanum. The obtained regression model showed high correlation $\left(R^{2}=0.9587\right)$. Under the optimal condition of ethanol concentration $73.5 \%$, extraction time $38.3 \mathrm{~min}$, and temperature $62.5^{\circ} \mathrm{C}$, the predicted value for TFC was found to be $101.7 \mathrm{mg} / \mathrm{g}$. The major compounds of Hypericum formosanum, including hyperoside, astilbin, quercitrin, and quercetin, were identified by UPLC-DAD-MS. The extract of Hypericum formosanum reduced AGE-induced MMP-1 protein expression. The major flavonoid compound in Hypericum formosanum could be correlated to its MMP-1 inhibitory activity. HFE may have medicinal value for applications in the cosmetics industry.

Acknowledgments: We are grateful to Chang, San-Xian from the Hualien District Agricultural Research and Extension Station Council of Agriculture, Taiwan, for botany identification.

Author Contributions: Ho-Shin Huang carried out all the experiments; Ho-Shin Huang and Ean-Tun Liaw designed all the experiments and analyzed the data; Ho-Shin Huang and Ean-Tun Liaw wrote the manuscript.

Conflicts of Interest: The authors declare no conflict of interest.

\section{References}

1. Nahrstedt, A.; Butterweck, V. Lessons learned from herbal medicinal products: The example of St. John's Wort (perpendicular). J. Nat. Prod. 2010, 73, 1015-1021. [CrossRef] [PubMed]

2. Carlo, G.D.; Borrelli, F.; Rrnst, E.; Izzo, A.A. St. John's wort: Prozac from the plant kingdom. Trends Pharmacol. Sci. 2001, 22, 292-297. [CrossRef]

3. Greeson, J.M.; Sanford, B.; Monti, D.A. St. John's wort (Hypericum perforatum): A review of the current pharmacological, toxicological, and clinical literature. Psychopharmacology 2001, 153, 402-414. [CrossRef] [PubMed]

4. Butterweck, V.; Schmidt, M. St. John's wort: Role of active compounds for its mechanism of action and efficacy. Wien. Med. Wochenschr. 2007, 157, 356-361. [CrossRef] [PubMed]

5. Tatsis, E.C.; Boeren, S.; Exarchou, V.; Troganis, A.N.; Vervoort, J.; Gerothanassis, I.P. Identification of the major constituents of Hypericum perforatum by LC/SPE/NMR and/or LC/MS. Phytochemistry 2007, 68, 383-393. [CrossRef] [PubMed]

6. Barnes, J.; Anderson, L.A.; Phillipson, J.D. St John's wort (Hypericum perforatum L.): A review of its chemistry, pharmacology and clinical properties. J. Pharm. Pharmacol. 2001, 53, 583-600. [CrossRef] [PubMed]

7. Skalkos, D.; Stavropoulos, N.E.; Tsimaris, I.; Gioti, E.; Stalikas, C.D.; Nseyo, U.O. The lipophilic extract of Hypericum perforatum exerts significant cytotoxic activity against T24 and NBT-II urinary bladder tumor cells. Planta Med. 2005, 71, 1030-1035. [CrossRef] [PubMed]

8. Boveris, A.D.; Puntarulo, S. Free radical scavenging actions of natural antioxidants. Nutr. Res. 1998, 18, 1545-1547. [CrossRef]

9. Hollman, P.C.H.; Katan, M.B. Absorption, metabolism, and health effects of dietary flavonoids in man. Biomed. Pharmacother. 1997, 51, 305-310. [CrossRef] 
10. Pietta, P.G. Flavonoids as antioxidants. J. Nat. Prod. 2000, 63, 1035-1042. [CrossRef] [PubMed]

11. Liu, Y.; Wang, H.; Cai, X. Optimization of the extraction of total flavonoids from Scutellaria baicalensis Georgi using the response surface methodology. J. Food Sci. Technol. 2015, 52, 2336-2343. [CrossRef] [PubMed]

12. Ramic, M.; Vidovic, S.; Zekovic, Z.; Vladic, J.; Cvejin, A.; Pavlic, B. Modeling and optimization of ultrasound assisted extraction of polyphenolic compounds from Aronia melanocarpa by products form filter tea factory. Ultrason. Sonochem. 2015, 23, 360-368. [CrossRef] [PubMed]

13. Rostagno, M.A.; Palma, M.; Barroso, C.G. Ultrasound assisted extraction of soy isoflavones. J. Chromatogr. A 2003, 1012, 119-128. [CrossRef]

14. Sampaio, P.N.; Calado, C.R.C.; Sousa, L.; Bressler, D.C.; Pais, M.S.; Fonseca, L.P. Optimization of the culture medium composition using response surface methodology for new recombinant cyprosin B production in bioreactor for cheese production. Eur. Food Res. 2010, 231, 339-346. [CrossRef]

15. Ballarad, T.S.; Mallikarjunan, P.; Zhou, K.; Okkefe, S.F. Optimizing the Extraction of Phenolic Antioxidants from Peanut Skins Using Response Surface Methodology. J. Agric. Food. Chem. 2009, 57, 3064-3072. [CrossRef] [PubMed]

16. Hayouni, E.A.; Abedrabba, M.; Bouix, M.; Hamdi, M. The effects of solvents and extraction method on the phenolic contents and biological activities in vitro of Tunisian Quercus coccifera L. and Juniperus phoenicea L. fruit extracts. Food Chem. 2007, 105, 1126-1134. [CrossRef]

17. Huang, W.; Li, Z.; Niu, H.; Li, D.; Zhang, J. Optimization of operating parameters for supercritical carbon dioxide extraction of lycopene by response surface methodology. J. Food Eng. 2008, 89, 298-302. [CrossRef]

18. Pompeu, D.R.; Silva, E.M.; Rogez, H. Optimization of the solvent extraction of phenolic antioxidants from fruits of Euterpe oleracea using response surface methodology. Bioresour. Technol. 2009, 100, 6076-6082. [CrossRef] [PubMed]

19. Myers, R.H.; Montgomery, D.C. Response Surface Methodology: Process and Product Optimization Using Design Experiments, 2nd ed.; John Wiley \& Sons: Hoboken, NJ, USA, 2002.

20. Xi, J.; Wang, B.S. Optimization of ultrahigh-pressure extraction of polyphenolic antioxidants from green tea by response surface methodology. Food Bioprocess Technol. 2013, 6, 2538-2546. [CrossRef]

21. Dayana, P.S.; Bakthavatsalam, A.K. Optimization of phenol degradation by the microalga Chlorella pyrenoidosa using Plackett-Burman Design and Response Surface Methodology. Bioresour. Technol. 2016, 207, 150-156. [CrossRef] [PubMed]

22. Wang, T.; Liang, H.; Yuan, Q. Optimization of ultrasonic-stimulated solvent extraction of sinigrin from Indian mustard seed (Brassica juncea L.) using response surface methodology. Phytochem. Anal. 2011, 22, 205-213. [CrossRef] [PubMed]

23. Pinelo, M.; Rubilar, M.; Sineiro, J.; Nunez, M.J. Effect of solvent, temperature, and solvent-to-solid ration the total phenolic content and antiradical activity of extracts from different components from grape pomace. J. Agric. Food Chem. 2005, 53, 2111-2117. [CrossRef] [PubMed]

24. Fisher, G.J.; Kang, S.; Varani, J.; Bata-Csorgo, Z.; Wan, Y.; Datta, S.; Voorhees, J.J. Mechanisms of photoaging and chronological skin aging. Arch. Dermatol. 2002, 138, 1462-1470. [CrossRef] [PubMed]

25. Giacomoni, P.U.; Rein, G. Factors of skin ageing share common mechanisms. Biogerontology 2001, 2, $219-229$. [CrossRef] [PubMed]

26. Browniee, M.M. Advanced protein glycation in diabetes and aging. Annu. Rev. Med. 1995, 46, $223-234$. [CrossRef] [PubMed]

27. Wondrak, G.T. Let the sun shine in: Mechanisms and potential for therapeutics in skin photodamage. Curr. Opin. Investig. Drugs 2007, 8, 390-400. [PubMed]

28. Farris, P.K. Innovative cosmeceuticals: Sirtuin activators and anti-glycation compounds. Semin. Cutan. Med. Surg. 2011, 30, 163-166. [CrossRef] [PubMed]

29. Pageon, H. Reaction of glycation and human skin: The effects on the skin and its components, reconstructed skin as a model. Pathol. Biol. 2010, 58, 226-231. [CrossRef] [PubMed]

30. Fisher, G.J.; Quan, T.; Purohit, T.; Shao, Y.; Cho, M.K.; He, T.; Varani, J.; Kang, S.; Voorhees, J.J. Collagen fragmentation promotes oxidative stress and elevates matrix metalloproteinase- 1 in fibroblasts in aged human skin. Am. J. Pathol. 2009, 174, 101-114. [CrossRef] [PubMed]

31. Chen, Q.; Jin, M.; Yang, F.; Zhu, J.; Xiao, Q.; Zhang, L. Matrix metalloproteinases: Inflammatory regulators of cell behaviors in vascular formation and remodeling. Mediat. Inflamm. 2013, 2013. [CrossRef] [PubMed] 
32. Yang, H.M.; Ham, Y.M.; Yoon, W.J.; Roh, S.W.; Jeon, Y.J.; Oda, T. Quercitrin protects against ultraviolet B-induced cell death in vitro and in an in vivo zebrafish model. Photochem. Photobiol. B 2012, 114, 126-131. [CrossRef] [PubMed]

33. Morand, C.; Manach, C.; Crespy, V.; Remesy, C. Quercetin 3-O-beta-glucoside is better absorbed than other quercetin forms and is not present in rat plasma. Free Radic. Res. 2000, 33, 667-676. [CrossRef] [PubMed]

34. Hanamura, T.; Hagiwara, T.; Kawagishi, H. Structural and functional characterization of polyphenols isolated from Acerola (Malpighia emarginata DC.) fruit. Biosci. Biotechnol. Biochem. 2005, 69, 280-286. [CrossRef] [PubMed]

35. Jang, D.S.; Kim, J.M.; Kim, J.; Yoo, J.L.; Kim, Y.S.; Kim, J.S. Effects of compounds isolated from the fruits of Rumex japonicus on the protein glycation. Chem. Biodivers. 2008, 5, 2718-2723. [CrossRef] [PubMed]

36. Galanakis, C.M.; Tornberg, E.; Gekas, V. Clarification of high-added value products from olive mill wastewater. J. Food Eng. 2010, 99, 190-197. [CrossRef]

37. Boots, A.W.; Haenen, G.R.; Bast, A. Health effects of quercetin: From antioxidant to nutraceutical. Eur. J. Pharmacol. 2008, 585, 325-337. [CrossRef] [PubMed]

38. Cho, J.W.; Cho, S.Y.; Lee, S.R.; Lee, K.S. Onion extract and quercetin induce matrix metalloproteinase-1 in vitro and in vivo. Int. J. Mol. Med. 2010, 25, 347-352. [PubMed]

39. Jnawali, H.N.; Lee, E.; Shin, A.; Park, Y.G.; Kim, Y. Effect of Quercetin in the UV-Irradiated Human Keratinocyte HaCaT Cells and A Model of Its Binding To p38 MAPK. Bull. Korean Chem. Soc. 2014, 35, 2787-2790. [CrossRef]

40. Lee, S.Y. Synergistic effect of maclurin on ginsenoside compound K induced inhibition of the transcriptional expression of MMP-1 in HaCaT human keratinocyte cells. J. Ginseng Res. 2017, in press. [CrossRef]

41. Zhou, J.; Zhou, T.; Chen, M.; Jiang, M.; Wang, X.; Liu, Q.; Zhan, Z.; Zhang, X. Research progress on synergistic anti-tumor mechanisms of compounds in Traditional Chinese Medicine. J Tradit. Chin. Med. 2014, 34, 100-105. [CrossRef]

42. Kim, D.O.; Chun, O.K.; Kim, Y.J.; Moon, H.Y.; Lee, C.J. Quantification of polyphenolics and their antioxidant capacity in fresh plums. J. Agric. Food Chem. 2003, 51, 6509-6515. [CrossRef] [PubMed]

Sample Availability: Samples of the compounds are not available from the authors.

(c) 2017 by the authors. Licensee MDPI, Basel, Switzerland. This article is an open access article distributed under the terms and conditions of the Creative Commons Attribution (CC BY) license (http://creativecommons.org/licenses/by/4.0/). 